\title{
The contribution of forest remnants within industrial area to threatened mammal conservation: A case study in liquefied natural gas industry in Bontang, Indonesia
}

\author{
SUDRAJAT ${ }^{1, \vartheta}$, MINTORO DWI PUTRO ${ }^{2, \bullet \bullet}$ \\ ${ }^{1}$ Laboratory of Ecology, Faculty of Mathematics and Natural Sciences, Universitas Mulawarman. Jl. Barong Tongkok, Gunung Kelua, Samarinda 75123 , \\ East Kalimantan, Indonesia. Tel.: +62-541-749140, `email: sudrajat.fmipa@gmail.com \\ ${ }^{2}$ Laboratory of Systematics, Faculty of Mathematics and Natural Sciences, Universitas Mulawarman. Jl. Barong Tongkok, Gunung Kelua, Samarinda \\ 75123, East Kalimantan, Indonesia. Tel.: +62-541-749140, •`email: mintorodwi@ gmail.com
}

Manuscript received: 14 July 2019. Revision accepted: 22 July 2019.

\begin{abstract}
Sudrajat, Putro MD. 2019. The contribution of forest remnants within industrial area to endemic and threatened mammal conservation: A case study in liquefied natural gas industry in Bontang, East Kalimantan, Indonesia. Biodiversitas 20: $2257-2265$. Tropical forests harbor high biodiversity, while natural protected area is one of the approaches for biodiversity conservation. However, the conversion of natural forests for various purposes has caused forest fragmentation. A novel strategy of conservation is proposed in the form of protected area within industrial estate as the contribution of industrial company in biodiversity conservation. The purpose of this study is to document the endemic and threatened species of mammals existing at two forest fragments with extent of 15 ha and 7.4 ha in a natural gas refinery industry area in Bontang, East Kalimantan and their potential as biodiversity conservation areas. Mammals were monitored at the two forest fragments through direct surveys, trace identification, mist nets, and camera traps. The results of the study show that according to IUCN Red List there were 23 mammal species (belonging to 18 genera, 15 families and six orders) of conservation concern found within the forest fragments including one species is under Critically Endangered, two are Endangered, four are Vulnerable, ten are Least Concern, one is Near Threatened and three are Not Evaluated. Four of those species are considered as endemic, namely Bornean orangutan, Pongo pygmaeus morio, Müller's gibbon, Hylobates muelleri, Proboscis monkey, Nasalis larvatus and East Bornean slow loris, Nycticebus menagensis. These findings suggest that forest fragments located in the environment of industrial estate can be considered as important conservation strategy if they are well preserved and maintained.
\end{abstract}

Keywords: Conservation, endemic and threatened mammals, industrial estate, remnant forest

\section{INTRODUCTION}

Fragmentation affects the components of habitat in an ecosystem, among them include the change in temperature, humidity and intensity of sunlight entering the forest. The effect of these changes will disrupt existing forest animal life. The fragmentation process results in the reduction of native habitat, creating bordered areas with new conversion areas with new activities. The process of habitat fragmentation will cause a decrease in primary habitat area, add new boundary space, isolation of new fragmentation bag pockets. This condition will reduce biodiversity by 13 to $75 \%$ by destroying the main function of ecosystems through decreasing biomass and nutrient cycle changes (Gunawan and Prasetyo 2013; Haddad et al. 2015)

Harris (1984) stated that the most threatened species are shown to have small populations. This happens due to limited space and availability of animal feed and exploitation of remaining habitats with carnivores and insectivores rank first as the most threatened groups. Keinath et al. (2017) stated that the life history of animal in a habitat can be used as a predictor of fragmentation effects with animals requiring specific habitat are more sensitive to fragmentation.
Kutai National Park (KNP) is a home to what is likely to be East Kalimantan's largest population of the Critically Endangered eastern subspecies of the Bornean Orangutan, Pongo pygmaeus morio. It also hosts an astounding diversity of other species including around 80 species of mammal, 369 of bird and 1287 of plant. The park plays an important role in regulating water supply to neighboring towns and attracts tourism, while its forests serve as a valuable carbon sink (Lee et al. 2019). Since the opening of the Trans Kalimantan highway along $65 \mathrm{~km}$ from BontangSangatta in 1996, KNP as a national protected area in East Kalimantan has faced very strong human population pressure, mainly because of the fast growth of two industrial cities namely Bontang and Sangatta. This population pressure mainly has been occurred in the intensive use zone of the park and it has impacted the area on either side of the road, both in the form of permanent and semi-permanent settlements. Other forms of anthropogenic pressures on the KNP area include illegal logging, illegal mining, land conversion into public facilities and social facilities, and land grabbing for agricultural purposes. These deforestation, forest degradation and forest fragmentation process are the major factors of threatening process and loss of biodiversity in these areas. 
The process of land conversion of KNP areas from natural ecosystem to infrastructure and fertilizer industry, liquefied natural gas (LNG) refineries and social infrastructure will lead to the degradation of natural habitat where these industrial activities take place, including the potential impacts on biodiversity. For example, there are remnants forest within a liquefied natural gas industrial estate in the areas which include mangrove forests and Dipterocarpaceae forests although the extent is quite small with areas of less than 50 ha each. The remnants of these forests are still connected with KNP through a narrow corridor of forest along the Bontang Watershed Protection Forest. This condition is thought to affect the composition and abundance of species according to the level of fragmentation that occurs in the landscape where some species require large area.

Until now the anthropogenic pressures on the KNP areas still continue which can restrict wildlife movements inside the KNP area while there is a potential area in the form of forest fragments located in nearby industrial estate which can serve as refugia for such animals. A research on the contribution of industrial landscape for the conservation of endemic and endangered mammal is very interesting to enrich similar study on flora conservation as conducted by Budiharta (2010) in the context of logging industry and Fiqa et al. (2019) in the context of coal mining industry. The aim of this study is to identify mammalian diversity within remnants of forest fragments in a liquefied natural gas processing industry in Bontang, East Kalimantan. This research is expected to contribute for the improvement of wildlife management and conservation of mammals in cooperation with industrial activities.

\section{MATERIALS AND METHODS}

\section{Study and location}

The research was conducted from November 2018 until March 2019 in forest fragments in a liquefied natural gas industry area in Bontang, East Kalimantan Indonesia (Figure 1). The research location has an altitude of $0-5 \mathrm{~m}$ above sea level and is a secondary dipterocarp forest which had been logged more than 40 years ago. The structure of vegetation is a mixed type of dipterocarp forest consisting of several strata in which the first layer is dominated by Shorea parvifolia, S. smithiana, and Dipterocarpus cornutus. Other plant species are Kompassia excelsa, Alstonia sp., and Dillenia sp. In sub-canopy layer, there are Eusideroxylon zwageri, Ficus sp and various types of rattan as a group of climbing plants.(Figure 2).

\section{Data collection and sampling procedure}

The sampling procedure used line transect method and data inventory used direct and indirect observation techniques based on traces, scratches, feeds and sounds. Camera trap was used as supporting method in which two traps were placed in each station, one on the ground and another in the understory vegetation at 1-2 $\mathrm{m}$ above the ground. The identification of mammal species used the "Field Guide to the Mammals of Borneo" book (Payne et al. 1985).
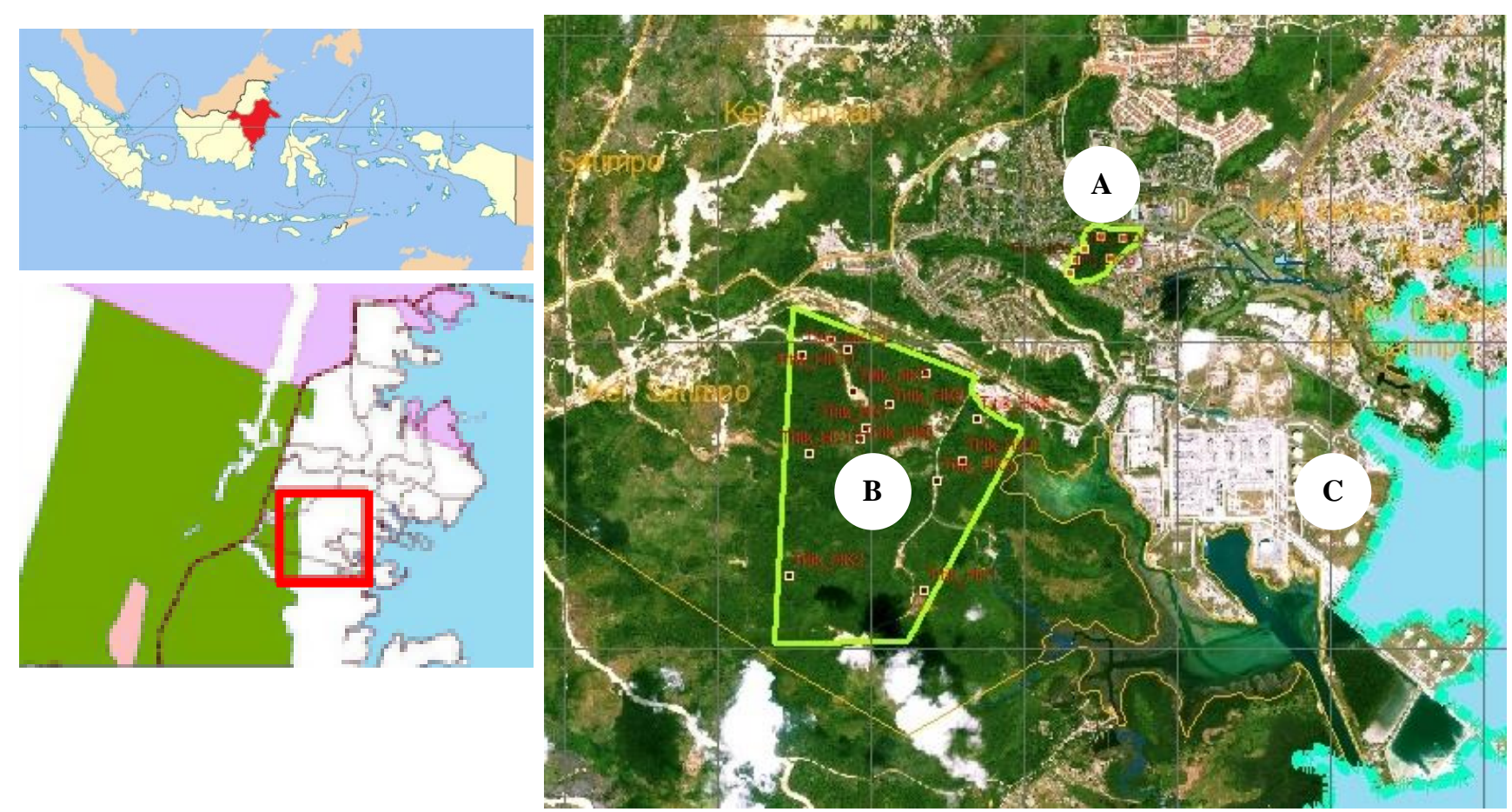

Figure 1. The map is a study location in the remnants of the forest within the liquefied natural gas industry area in Bontang, East Kalimantan, Indonesia. A. Natural forest isolated in the area, B. Company conservation forest area, C. Operational area of liquefied natural gas liquefaction plant 


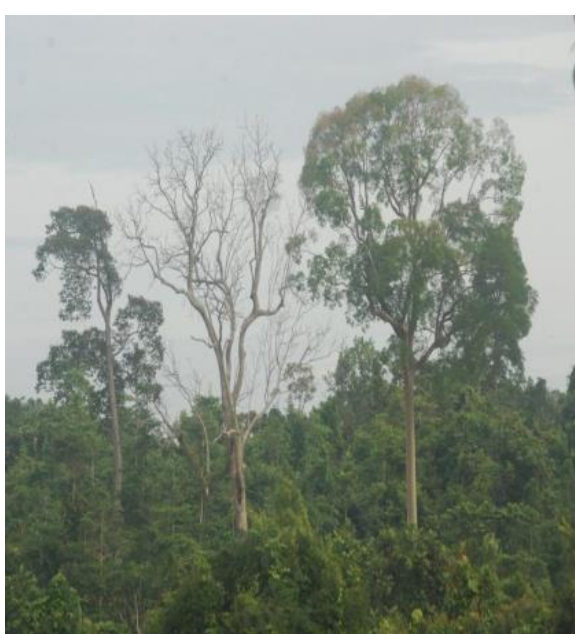

A

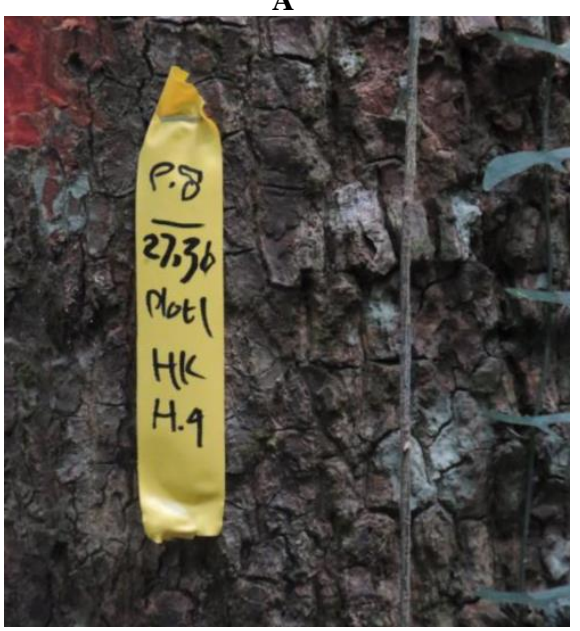

D

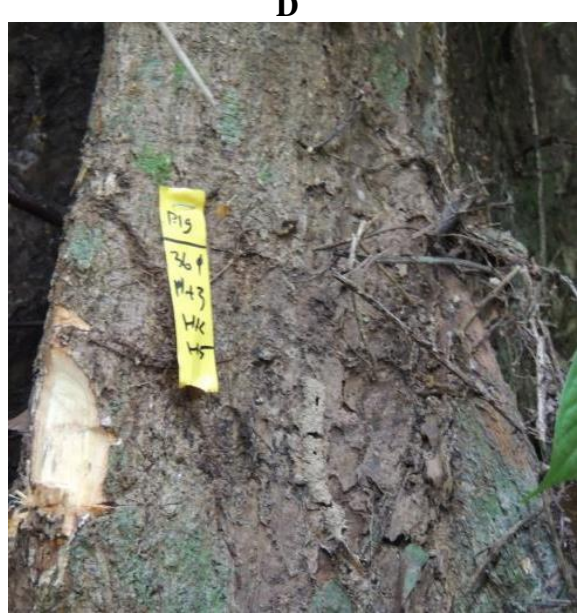

G

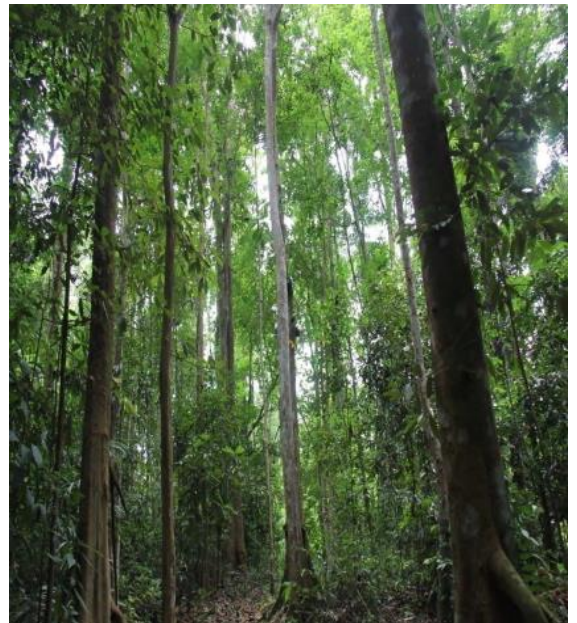

B

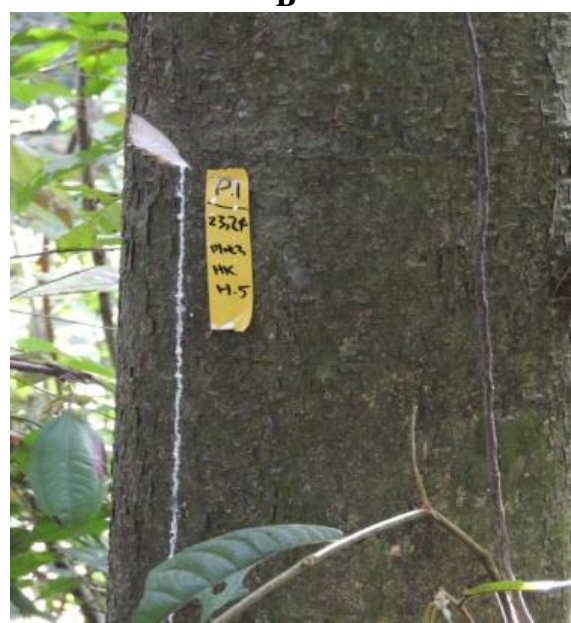

$\mathbf{E}$

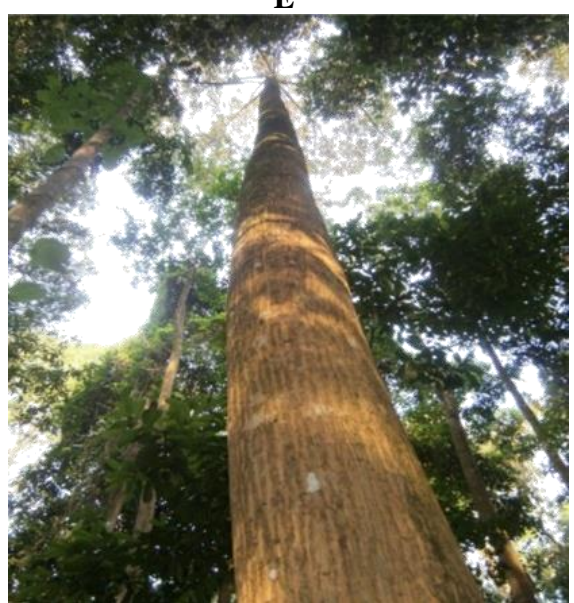

$\mathbf{H}$

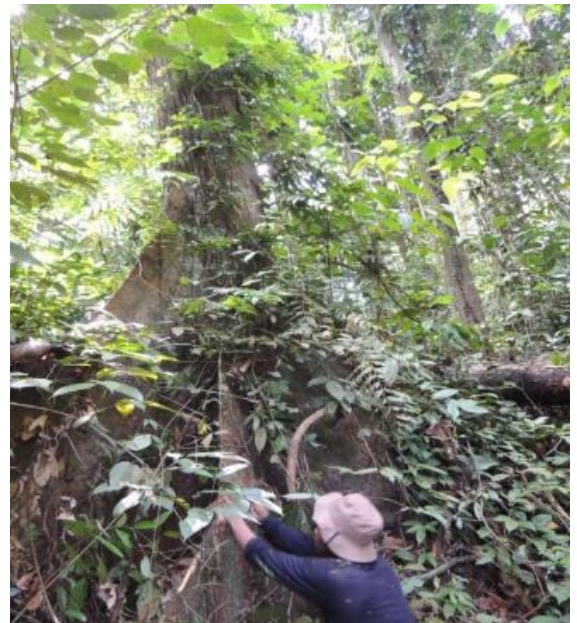

C

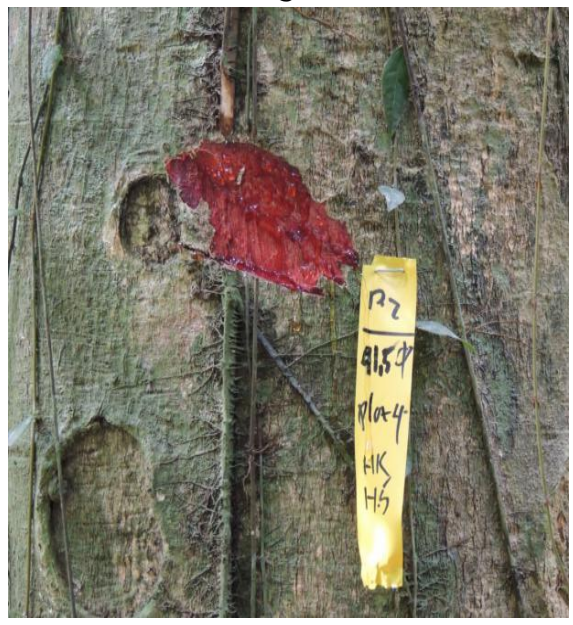

$\mathbf{F}$

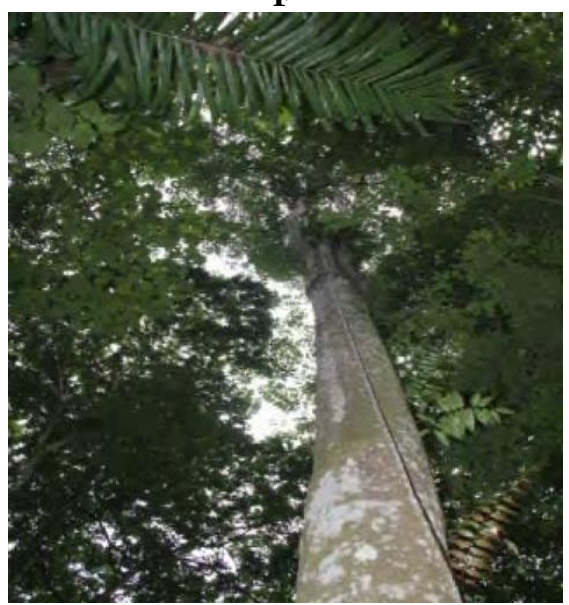

I

Figure 2. The illustration structure of vegetation is a mixed type of dipterocarp forest in the forest remnants within liquefied natural gas industry area in Bontang, East Kalimantan, Indonesia. A. Forests on the Bontang Liquid Natural Gas industry border, B. Vegetation in Natural Forest isolated in Bontang natural gas liquefaction industrial area, C. Old tree, D. Schima wallichii, E. Alstonia scholaris, F. Planchonia sp., G-H. Shorea sp., I. Dillenia grandis

\section{Installation of camera trap}

The camera traps were mounted on tree trunks with a height of $30-50 \mathrm{~cm}$ from the ground without using bait. The camera trap was set to operate continuously to take three series without intervals between successive triggers. The camera was installed for 31 days, then the camera was retrieved if the film had remaining exposures or the time and date stamped on the final exposure. After cameras were retrieved, films were processed and examined for identification of mammals. Each photo was identified as an unidentified picture. Assumptions used to identify individuals using independent photos are: (i) sequential 
photos or sequels from different species on one film number; (ii) sequential photos or sequels from individuals of the same species in a number of films with a span of more than 30 minutes or sequential photos or sequels from different individuals if they can be clearly distinguished; and (iii) the same individual photos or same sequential or sequel types in one film number (Brien et al. 2003).

\section{Analysis of relative abundance index}

The relative abundance index provides an estimate of abundance based on the number of photos and efforts so that it can see the comparisons between different plots (Brien et al. 2003). The relative abundance index was calculated using the formula:

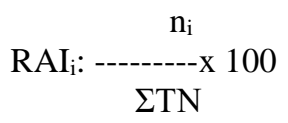

Where:

$\mathrm{RAI}_{\mathrm{i}}$ : Relative Abundance Index (relative abundance index per 100 days of trapping)

$\mathrm{n}_{\mathrm{i}} \quad$ : Number of videos or images independent species to $-\mathrm{i}$

$\Sigma \mathrm{TN}$ : Number of days active on camera

\section{RESULTS AND DISCUSSION}

The number of identifiable mammal species at the studied locations is 23 , consisting of 20 genera, 15 families and 8 orders (Table 1). Eleven species were recorded from direct encounters in the field (Hylobates muelleri, Nasalis larvatus, Nycticebus menagensis, Macaca fascicularis, Macaca nemestrina, Callosciurus notatus, Tupaia minor, Paradoxurus hermaphroditus); nine were recorded from traps, camera traps and traces (Pongo pygmaeus, Cynoterus brachyotis, Macroglossus minimus, Dyacopterus spadiceus, Rattus tiomanicus, Mus castaneus, Viverra tangalunga, Felis chatus, Sus barbatus, Muntiacus muntjak, Hystrix brachyura and Echinosorex gymnurus.

Of all the species recorded, five species are listed as protected animal species under the Decree of the Indonesian Minister of Environment and Forestry Number 20/2018: N. larvatus, $N$. coucang, $P$. pygmaeus, $M$. muntjak and $H$. muelleri, with the population of the latter is considered to be in decline by the International Union for Conservation of Nature (IUCN 2018) and three are included in one of the Appendices of the Convention on International Trade in Endangered Species (CITES) of Wild Fauna and Flora.

The results of the trap camera analysis showed the presence of Macaca fascicularis, Macaca nemestrina, and Sus barbatus. Similarly, Table 2 shows that mammals that have a wide distribution throughout the locations are Macaca fascicularis, Macaca nemestrina and Sus barbatus. These types of mammals are generalist or animals that have a high survival ability with diverse feed patterns and habitat conditions. Macaca fascicularis and Macaca nemestrina are able to survive throughout the year by eating only one or several types of plants. Sus barbatus eats fallen fruits, seeds, roots, leaves and other plant materials to terrestrial animals including worms and small animals. It appears that the presence of a certain mammal is determined by the suitability to habitat range, the availability of food, and the ability to compete with other species.

Morrison et al. (1992) stated that the probability of the presence of certain species in an area is determined by several factors including food, water, nest material, environmental heterogeneity, competitors, predators and diseases. Species which have the ability to increase their population and roam everywhere when habitat fragmentation occurs are adaptable species. Because of this rationale, species that get advantages from human activities are not species of concern to be protected. Instead, protection should be focused on self-struggling species to be survived in habitats that are rapidly disappearing (Harris 1984). If existing habitats size is smaller than the minimum area needed by a species, individuals of such species migh not be found in the habitat fragment (Robbins 1980).

The remnant of mixed dipterocarp forests in the complex of liquefied natural gas industrial estates in covering 15 ha and 7.4 ha of terrestrial forests have been supported by the presence of several species of mammals. Some of the animals that are protected under the IUCN and Indonesia Regulation No P.20 / 2018. As many as 17 of 23 species of mammals that can be identified (33.33\%) are important species based on IUCN criteria. Orangutans, proboscis monkeys and gibbons are the only conservation priority species recorded in the fragments of forest patches and contiguous forests, respectively.

Despite the small extent, these areas are very important for wildlife habitat. This forested habitat is still connected to the main area of the Kutai National Park, through secondary forests and community gardens. This is the statement of Bennett and Mulongoy (2006), that wildlife corridors naturally have a positive impact helping the movement of immigration to new habitats.

Pongo pygmaeus morio is a protected species under the status of Critically Endangered. Reports on the presence of orangutans, proboscis monkeys, gibbons and lemurs in the habitat of forest fragments in the Bontang liquefied natural gas industry attract attention, and this requires an effort to protect them. Some possible way to do this by strengthening the status of the area by assigning it as high conservation value forest (HCFV) (Budiharta 2010; Fiqa et al 2019). The orangutan population in Kalimantan is threatened by the pressure of forest conversion to agriculture and poaching. Abram et al. (2015) predicted that this orangutan subspecies would become extinct for the next 10 years if the pressures continue unabated. This subspecies is declining fast due to the rapid loss of suitable habitat (Struebig et al. 2015). The presence of orangutans in the area of this research indicates that the existence of forest fragments still support orangutan life. The index value of orangutans based on camera trap monitoring is 6.4, indicating that this animal is suspected to roaming across habitats. These forest fragments are still connected through corridor to the KNP forest and Bontang Protection Forest which are the original habitats of orangutans. 
Table 1. List of mammal species identified at the study areas in the forest remnants in a liquefied natural gas industrial area in Bontang, East Kalimantan, Indonesia

\begin{tabular}{|c|c|c|c|c|c|c|c|}
\hline \multirow{2}{*}{ Order family } & \multirow{2}{*}{ Species name } & \multirow{2}{*}{ Common name } & \multicolumn{2}{|c|}{ Location } & \multirow{2}{*}{$\begin{array}{c}\text { Record } \\
\text { by }\end{array}$} & \multicolumn{2}{|c|}{$\begin{array}{c}\text { Conservation status } \\
\end{array}$} \\
\hline & & & $\overline{\mathbf{C A}}$ & $\mathbf{N F}$ & & P.20/ MENLHK/ 2018 & Status IUCN \\
\hline \multicolumn{8}{|l|}{ Primate } \\
\hline Pongidae & Pongo pygmaeus & Bornean orangutan $(\mathrm{E})$ & & $\sqrt{ }$ & $\mathrm{CT}$ & $\mathrm{P}$ & $\mathrm{CR}$ \\
\hline Hylobatidae & Hylobates muelleri & Müller's gibbon (E) & & $\sqrt{ }$ & $\mathrm{O}$ & $\mathrm{P}$ & EN \\
\hline Cercopithecidae & Nasalis larvatus & Proboscis monkey $(\mathrm{E})$ & & $\sqrt{ }$ & $\mathrm{O}$ & $\mathrm{P}$ & EN \\
\hline Lorisidae & Nycticebus menagensis & East Bornean slow loris (E) & $\sqrt{ }$ & & $\mathrm{O}$ & $\mathrm{P}$ & VU \\
\hline Cercopithecida & Macaca fascicularis & Long-tailed macaque & $\sqrt{ }$ & & $\mathrm{O}$ & NP & $\mathrm{LC}$ \\
\hline Cercopithecida & Macaca nemestrina & Sunda pig-tailed macaque & $\sqrt{ }$ & $\sqrt{ }$ & $\mathrm{CT}$ & NP & VU \\
\hline Cercopithecida & Presbytis rubicunda & Maroon langur $(\mathrm{E})$ & $\sqrt{ }$ & & $\mathrm{O}$ & NP & $\mathrm{LC}$ \\
\hline \multicolumn{8}{|l|}{ Chiroptera } \\
\hline Pteropodidae & Cynoterus brachyotis & Short-nosed fruit bat & $\sqrt{ }$ & $\sqrt{ }$ & $\mathrm{N}$ & NP & NE \\
\hline Pteropodidae & Macroglossus minimus & The long-tongued fruit bat & $\sqrt{ }$ & $\sqrt{ }$ & $\mathrm{N}$ & NP & $\mathrm{NE}$ \\
\hline Pteropodidae & Dyacopterus spadiceus & Dayak fruit bat & $\sqrt{ }$ & & $\mathrm{N}$ & NP & NT \\
\hline \multicolumn{8}{|l|}{ Rodentia } \\
\hline Sciuridae & Callosciurus notatus & Plantain squirrel & $\sqrt{ }$ & & $\mathrm{T}$ & NP & $\mathrm{LC}$ \\
\hline Muridae & Rattus tiomanicus & Malayan Field Rat & $\sqrt{ }$ & & $\mathrm{T}$ & NP & $\mathrm{LC}$ \\
\hline Muridae & Mus castaneus & Southeastern Asian house mouse & $\sqrt{ }$ & & $\mathrm{T}$ & NP & $\mathrm{NE}$ \\
\hline Hystricidae & Hystrix brachyura & Malayan Porcupine & $\sqrt{ }$ & & $\mathrm{CT}$ & NP & $\mathrm{LC}$ \\
\hline \multicolumn{8}{|l|}{ Scandentia } \\
\hline Tupaiidae & Tupaia minor & Pygmy Treeshrew & $\sqrt{ }$ & & $\mathrm{O}$ & NP & $\mathrm{LC}$ \\
\hline Tupaiidae & Tupaia picta & Painted Treeshrew & $\sqrt{ }$ & & $\mathrm{CT}$ & NP & $\mathrm{LC}$ \\
\hline \multicolumn{8}{|l|}{ Carnivora } \\
\hline Viverridae & Paradoxurus hermaphroditus & Asian palm civets & $\sqrt{ }$ & & $\mathrm{F}$ & NP & $\mathrm{LC}$ \\
\hline Viverridae & Viverra tangalunga & Malayan Civet & $\sqrt{ }$ & & $\mathrm{CT}$ & NP & NT \\
\hline Felidae & Felis bengalensis & Leopard Cat & $\sqrt{ }$ & & $\mathrm{CT}$ & NP & VU \\
\hline \multicolumn{8}{|l|}{ Artiodactyla } \\
\hline Suidae & Sus barbatus & Bearded Pig & & & $\mathrm{CT}$ & NP & VU \\
\hline Cervidae & Muntiacus muntjak & Red Muntjac & $\sqrt{ }$ & $\sqrt{ }$ & $\mathrm{CT}$ & $\mathrm{P}$ & $\mathrm{LC}$ \\
\hline \multicolumn{8}{|l|}{ Insectivora } \\
\hline Erinaceidae & Echinosorex gymnurus & Moonrat & $\sqrt{ }$ & & $\mathrm{CT}$ & NP & $\mathrm{LC}$ \\
\hline
\end{tabular}

Note: Locations: CA: conservation area (15 ha); NF: natural forest (7 ha). Method of observation: CT: camera trap; F: Fecal Track; O: direct observation; T: traps; N: Miss net. Protection status based on the Decree of the Indonesian Minister of Environment and Forestry Number 20/2018: P: protected; NP: Not Protected. Protection status based on IUCN Red List category: EN: endangered; CR: Critically Endangered; VU: Vulnerable; NT: Near threatened; LC: Least Concern; NE: Not Evaluated. Additional note: E: Endemic

Table 2. Index of presence of wildlife mammals captured on camera traps at the forest remnants in liquefied natural gas area in Bontang, East Kalimantan

\begin{tabular}{|c|c|c|c|c|c|}
\hline Common name & Species name & Family & Day camera & $\begin{array}{c}\text { Total } \\
\text { independent photos }\end{array}$ & RAI \\
\hline Moonrat & Echinosorex gymnurus & Erinaceidae & 31 & 1 & 3.22 \\
\hline Bornean orangutan & Pongo pygmaeus morio & Pongidae & 31 & 2 & 6.45 \\
\hline Malayan Porcupine & Hystrix brachyura & Hystricidae & 31 & 2 & 6.45 \\
\hline Malayan Civet & Viverra tangalunga & Viverridae & 31 & 3 & 9.67 \\
\hline Painted Treeshrew & Tupaia picta & Tupaiidae & 31 & 4 & 12.90 \\
\hline Red Muntjac & Muntiacus muntjac & Cervidae & 31 & 4 & 12.90 \\
\hline Bearded Pig & Sus barbatus & Suidae & 31 & 6 & 19.35 \\
\hline Long-tailed macaque & Macaca fascicularis & Cercopithecidae & 31 & 7 & 22.58 \\
\hline Sunda pig-tailed macaque & Macaca nemestrina & Cercopithecidae & 31 & 8 & 25.80 \\
\hline
\end{tabular}




\section{BIODIVERSITAS}

Volume 20, Number 8, August 2019

Pages: 2257-2265

During the study, the flora found at the studied areas are plant species with fruits consumed by animals such as Syzygium spp., Barringtonia spp., Antidesma spp., Nauclea spp., Cratoxylum spp., Dillenia spp., Vitex spp., Lantana spp., Bauhinia spp., Macaranga spp., and Artocarpus spp.. Orangutans, as frugivores or fruit-eating animals, consume Borassodendron borneensis, eyes of the horn (Baccaurea stipulata), terap (Artocarpus anisophyllus), kapul (Baccaurea macrocarpa), banitan (Polyalthia sumatrana), kempas (Kompassia spp.), Monocarpia euneura, Diospyros sp. In addition to fruits, orangutans also eat Elai (Durio acutifolius), rattan (Calamus spp., Daemonorops spp., Korthalsia spp.), Zingiberaceae (Alpina sp., Globa sp.), leaves of Girroniera nervosa and Xantophyllum affine, and bark of Macaranga spp. (Kuncoro et al. 2008; Sayektiningsih 2013).

Proboscis monkeys can be found in this area because the existing forests are natural wildlife corridors that connect mangrove forests around the liquefied natural gas estate. Bismarck (2009) stated that proboscis monkeys have limited habitats in mangroves, forests around rivers, and peat swamp. Given that proboscis monkey feeding sources are located in mangrove forests, thus saving mangrove forests will also save the population of proboscis monkeys. This is in line with the report by Soerianegara et al. (1994) stating that some mangrove plants become the feeding sources of proboscis monkeys, including mangroves (Rhizophora apiculata), api-api (Avicennia alba), and rambai (Sonneratia caseolaris), along with other plants such as A. teysmanii, Ficus spp., Syzygium spp., Vitex pubescens, and Eugenia spp. Proboscis monkeys are folivores as the proportion of feeding of leaves reaches $92 \%$ of all feeds. However, other study stated that they are not true folivores since they also consume almost all parts of the plant which include roots, bark, leaves, fruit, and flowers (Supriatna and Wahyono 2000).

Owa kelawat (Hylobates muelleri) is the smallest animal in the Hylobatidae family. It is a tail-less primate spending all its life on trees (Payne et al. 2000). Hylobatidae family lives in groups and maintains its territory with sound or other special signs (Alikodra 2004). All of its life activities are carried out on the upper canopy. It has very short legs which almost never used for walking. To move around the places, other types of movement are used, namely by swinging from branch to another branch or to another tree. Therefore, the existence of forests or upper canopy areas is an important requirement for the survival of owa kelawat, especially places that have fruit trees as a feed source, such as cempedak, Artocarpus integer; rambutan, Nephelium lappaceum, etc.

Maroon langur, Presbytis rubicunda is a wild animal that lives in groups every day, always moves to find food, socializes and finds a place to rest, especially at night by looking for a large tree as the bed of the group. Maroon langur eating of $49 \%$ fruit, $11 \%$ flower, $37 \%$ leaf tip and small insects (Supriatna and Wahyono 2000). The presence of maroon langur in the studied areas indicates that the remaining forests in the company complex have supported the species in terms of food availability, socialization and rest.
ISSN: 1412-033X

E-ISSN: 2085-4722

DOI: $10.13057 /$ biodiv/d200821

The population of slow loris, Nycticebus menagensis, in the wild is decreasing due to the decline in habitat area and hunting. The IUCN categorizes Kalimantan slow loris under Vulnerable status, which continues to experience population decline in the last 3 generations (21-24 years) due to hunting and habitat loss (IUCN, 2008). Accordying Wiens (2002), vegetation is the main source of feed for lemurs in which nearly $60 \%$ comes from plants, namely fruits $(50 \%)$ and sap $(10 \%)$, while others are from animal feed sources $(40 \%)$. Generally, slow loris prefers feed sources in the form of sap $(34.9 \%)$ or plant fluids $(31.7 \%)$ and parts of flowers rather than fruits $(22.5 \%)$.

The presence of large mammals in the industrial estate of liquefied natural gas refinery suggests that greater effort is needed for ecological restoration (Budiharta et al. 2014; Budiharta et al. 2018). Nevertheless, the main weakness if the responsibility of conservation management is given to industry sectors, particularly the conservation of large mammals such as orangutans, proboscis monkeys and gibbons, is the adequacy of area extent to support those animal lives. Factors such as how to handling wildlife, competent human resources and sufficient financing need to be considered by the company.

The existence of species in industrial area must be followed up by more prudent management of the company. For example, the presence of the remnant forests can serve as mammals' corridor or biological corridor to connect habitats across various land uses, either the artificial or natural ecosystems in one landscape. Nonetheless, the existence of a corridor must involve various stakeholders and parties including the local community.

The presence of orangutans, bekantan, owa kelawat and kukang in the fragmented forests in the liquefied natural gas refinery estate presents two implications for conservationist. First, these mammals are found in industrial estate environments. This is certainly a joy and new hope for their existence. Second, bitterness appears as these mammals are isolated in forest remnants due to fragmentation. Although the carrying capacity of the habitat is likely to be sufficient to provide life support for some of the mammals, but not for other large-sized mammals. Nonetheless, it is expected that the remaining forests in this area will be maintained and not be changed to other uses.

In conclusion, the presence of endemic mammals of Kalimantan has been identified at the remnant forests in a liquefied natural gas industrial estate in Bontang, East Kalimantan. These animals turned out to be able to live side by side with human population and industrial activities. Some of them taking advantage of tree stands which provide top canopy as a place to live and feeding ground. This area offers a viable option as a conservation area for endemic and threatened mammals which gaining support from the company. A total of 23 mammal species found in these areas including one is under Critically Endangered, two are Endangered, four are Vulnerable, ten are Least Concern, one is Near Threatened and three are Not Evaluated belonging to 18 genera, 15 families and six orders. Four species are considered as endemic, namely orangutans, gibbons, mueleri, proboscis monkeys and slow 
lorises. This study suggests that forest fragments located in the industrial environment can be considered as important conservation strategy if they are well preserved and maintained.

\section{ACKNOWLEDGEMENTS}

The authors would like thank to the Head of Departement of Biology and Dean of Faculty of Mathematics and Natural Sciences, Mulawarman University, Samarinda, Indonesia who have financially supported this research and field team for sampling and analysis data. The authors declare that there are no conflicts of interest regarding the publication of this article.

\section{REFERENCES}

Abram NK, Meijaard E, Wells JA, Ancrenaz M, Pellier AS, Runting RK Gaveau D, Wich S, Tjiu A, Nurcahyo A. 2015. Mapping perceptions of species threats and population trends to inform conservation efforts: the Bornean orangutan case study. Divers Distrib 21: 487499.

Alikodra HS. 2004. Wisata berwawasan lingkungan. Media Konservasi 10 (2): 93-97. [Indonesian]

Bennett G, Mulongoy KJ. 2006. Review of experience with ecological networks, corridors and buffer zones. Secretariat of the Convention on Biological Diversity. Montreal.

Bismarck M. 2009. Biologi Konservasi Nasalis larvatus. Pusat Penelitian dan Pengembangan Hutan dan Konservasi Alam Kampus Balitbang Kehutanan. Bogor. [Indonesian]

Brien OTG, Kinnaird MF, Wibisono HT. 2003. Crouching tigers, hidden prey: Sumatran tiger and prey populations in a tropical forest landscape. Anim Conserv 6: 131-139.

Budiharta S, Meijaard E, Erskine PD, Rondinini C, Pacifici M, Wilson KA. 2014. Restoring degraded tropical forests for carbon and biodiversity. Environ Res Lett 9: 114020.

Budiharta S, Meijaard E, Gaveau DLA, Struebig MJ, Wilting A, KramerSchadt S, Niedballa J, Raes N, Maron M, Wilson KA. 2018. Restoration to offset the impacts of developments at a landscape scale reveals opportunities, challenges and tough choices. Global Environ Change 52, 152-161.

Budiharta S. 2010. Floristic composition at biodiversity protection area in Lubuk Kakap, District of Ketapang, West Kalimantan. Biodiversitas 11: 151-156.

Fiqa AP, Fauziah F, Lestari DA, Budiharta S. 2019. The importance of in-situ conservation area in mining concession in preserving diversity, threatened and potential floras in East Kalimantan, Indonesia. Biodiversitas 20: 198-210.

Gunawan H, Prasetyo LB. 2013. Fragmentasi Hutan: Teori yang mendasari penataan ruang hutan menuju pembangunan berkelanjutan.
Pusat Penelitian dan Pengembangan Konservasi dan Rehabilitasi. Bogor. [Indonesian]

Haddad NM, Brudvig LA,Clobert J, Davies KF, Gonzalez A, Holt RD, Lovejoy TE, Sexton JO, Austin MP, Collins CD, Cook WM, Damschen EI, Ewers RM, Foster BL, Jenkins CN, King AJ, Laurance WF, Levey DJ, Margules CR, Melbourne BA, Nicholls A O, Orrock JL, Song DX, Townshend JR.2015. Habitat fragmentation and its lasting impact on Earth's ecosystems: Sci Adv 1.http://advances.sciencemag.org/content/1/2/e1500052

Harris LD. 1984. The Fragmented Forest: Island Biogeography Theory and the Preservation of Biotic Diversity. University of Chicago Press. Chicago, IL.

International Union for Conservation of Nature and Natural Resources (IUCN). 2008. The IUCN red list of threatened species 2008. https://www.iucnredlist.org/species/39759/10263403

Keinath DA, Doak DF, Hodges KE, Prugh LR, Fagan W, Sekercioglu CH, Buchart SHM, Kauffman M. A global analysis of traits predicting species sensitivity to habitat fragmentation. Global Ecol Biogeogr 26, 115-127.

Kuncoro P, Sudaryanto, Yuni LPEK. 2008. Perilaku dan jenis pakan orangutan kalimantan (Pongo pygmaeus Linnaeus, 1760) di Kalimantan. J Biologi 11 (2): 64-69. [Indonesian]

Lee ATK, Carr, JA, Ahmad B, Arbainsyah, Ferisa A, HandokoY, Harsono R, Graham LLB, Kabangnga L, Kurniawan NP, Keßler PJA, Kuncoro P, Prayunita D, Priadiati A, Purwanto E, Russon AE, Sheil D, Sylva N, Wahyudi A and Foden WB. 2019. Reforesting for the climate of tomorrow: Recommendations for strengthening orangutan conservation and climate change resilience in Kutai National Park, Indonesia. IUCN.Gland, Switzerland.

Morrison ML, Marcot BG, Mannan RW. 1992. Wildlife-Habitat Relationship: Consepts and Applications. The University of Wisconsisn Press. Madison, Wisconsin.

Payne J, Francis CM, Phillips K, Kartikasari SN. 2000. Panduan Lapangan Mamalia di Kalimantan, Sabah, Serawak, dan Brunei Darussalam. Prima Centra Indonesia. Jakarta.

Payne J, Francis CM, Phillips K. 1985. A field guide to the mammals of Borneo. The Sabah Society. Kota Kinabalu. Malaysia. .

Robbins CS.1980. Effects of forest fragmentation on breeding bird populations in the Piedmont of the Mid-Atlantic Region. Atl Nat 33: 31-36.

Sayektiningsih T. 2013. Kajian potensi pembangunan koridor orangutan (Pongo pygmaeus morio) di daerah penyangga kawasan konservasi. Laporan hasil Penelitian. Balai Penelitian Teknologi Konservasi Sumber Daya Alam, Balai Penelitian dan Pengembangan Kehutanan, Kementerian Kehutanan, Balikpapan. [Indonesian]

Soerianegara I, Sastradipradja D, Alikodra HS, Bismarck M. 1994. Studi habitat, sumber pakan, dan perilaku bekantan (Nasalis larvatus) sebagai parameter ekologi dalam mengkaji sistem pengelolaan habitat hutan mangrove di Taman Nasional Kutai. Bogor: Laporan Akhir Pusat Penelitian Lingkungan Hidup, IPB. [Indonesian]

Struebig MJ, Andreas W, David LAG, Erik M, Robert JS. 2015. Targeted conservation to safeguard a biodiversity hotspot from climate and land-cover change. Curr Biol 25 (3): 372-378.

Supriatna J, Wahyono EH. 2000. Panduan Lapangan Primata Indonesia. Yayasan Obor Indonesia. Jakarta. [Indonesian]

Wiens F. 2002. Behavior dan ecology of wild slow lorises (Nycticebus coucang): Social organisation, infant care system dan diet. [Dissertation]. Bayreuth University, Bayreuth. 